\title{
Investigating the COVID-19 Self-Isolation Policy and Its Impact on Socioeconomic of Vulnerable Groups: An application of Rational and Non-Rational Thinking Models
}

\author{
AMIRUDIN AMIRUDIN ${ }^{1}$, JUMADIL SAPUTRA $^{2}$, TEUKU AFRIZAL $^{3, *}$, M. LATIP $^{4}$, \\ A. TARMIZI ${ }^{5}$ \\ ${ }^{1}$ Faculty of Humanities \\ Universitas Diponegoro \\ Kampus Tembalang, 50275 Semarang \\ INDONESIA \\ ${ }^{2}$ Faculty of Business, Economics and Social Development \\ Universiti Malaysia Terengganu \\ 21030 Kuala Nerus, Terengganu \\ MALAYSIA \\ ${ }^{3}$ Faculty of Social and Political Sciences \\ Universitas Diponegoro \\ Kampus Tembalang, 50275 Semarang \\ INDONESIA \\ ${ }^{4}$ Sekolah Tinggi Ilmu Administrasi Publik \\ Dumai Selatan, Dumai, 28826 Riau \\ INDONESIA \\ ${ }^{5}$ Universitas Islam Riau \\ Pekanbaru, 28284 Riau \\ INDONESIA
}

\begin{abstract}
The spread of the Corona Virus Disease (COVID-19) pandemic continues in impending world public health and bringing considerable human suffering. The present study investigates the vulnerable groups' reaction from informal sectors to the execution of the self-isolation policy of COVID-19 in Semarang City, Indonesia. This study is designed using a qualitative method with an ethnography approach. Using the binary opposition thinking pattern pioneered by Levi-Strauss, this study conducts the interview process with 25 informants in Semarang City. The data analysed using the response pattern of informants. We use the taxonomy analysis and finds three levels of vulnerability group; (a) jobs lost, (b) income decreased, and (c) delayed salary. The result of the analysis found that the group that obeys self-isolation is a rational thinking model. They stay at home, do not go to work, and no income. Also, the group who ignored self-isolation is a non-rational thinking model. They work, as usual, get their salaries, and believe that Covid-19 is a disaster; they pray for their safety to God. In conclusion, COVID 19 brings an economic impact on vulnerable groups in the forms of postponing, declining, and missing income. Even its circumstances are worse when self-isolation is forced. Thus, this study suggests that the government needs to assist vulnerable groups by focusing on strategic policies, such as strategies for survival, providing access to basic needs, and livelihood plans by providing access to improve livelihoods sustainably.
\end{abstract}

Key-Words: - Corona Virus Disease (COVID-19) pandemic, Self-Isolation Policy, Rational and Non-Rational Thinking Model, Vulnerable Groups

Received: December 1, 2020. Revised: May 2, 2021. Accepted: May 17, 2021. Published: June 1, 2021. 


\section{Introduction}

The spread of the Corona Virus Disease (COVID-19) pandemic continues to escalate throughout the world [1]. Officially, it emerged in China since the first human case reporting in Wuhan in December 2019 [2]. The COVID-19 pandemic is severely impending world public health and bringing considerable human suffering [3]. Hence, more than 200 countries and regions have affected by the epidemic, with the number of infections and death still increasing [4], [5]. Presently, there are 213 countries and territories affected worldwide, with the number of positive cases has reached 13,378,853 million, and 580,045 patients died. The highest country infected by COVID-19 is the United States with 7,016,851 million, Europe 2,987,256 million, Africa 523,403 thousand, Southeast Asia 1, 268,923 million [2]. The number of cases of global deaths that have occurred is 6.3 per cent.

As of July 15, 2020, Indonesia has reported that several positive COVID-19 patient cases also continue to grow, and the number of people infected COVID-19 has reached 81,667 thousand, 40,345 thousand patients recovered, and 3,873 patients died. The current death rate is 4.74 per cent [6]. It leads Indonesia to become the highest COVID-19 cases in Southeast Asia, after the Philippines and Singapore, and rank six in Asia according to the death numbers. Indonesia has conducted 1,201,014 tests or 4,389 tests per million of 273 million population. It is one of the lowest testing rates in the world [7]-[9]. According to Allard and Lamb [10], a review of data, however, indicated that the number of deaths might be highest than the number reported as died with acute symptoms but had not been confirmed were not yet counted in the official death figure. Since the first case was reported, the Indonesian government encouraged people who showed signs or had contacted COVID-19 patients to isolate themselves for 14 days. President Joko Widodo had urged Indonesians to work from home, learn from home, and worship at home to avoid the spread of the more massive coronavirus. Self-isolation in this context means staying at home to avoid contact with others. The president was made into a national policy determined through P.P. 21/2020 on Large-Scale Social Restrictions. This policy perceived much criticism and is considered a disaster because cases are still increasing [11].

The Semarang City Government has also implemented a self-isolation policy by establishing Community Activity Restrictions (C.A.R.) policy starting Monday, April 28, 2020. The C.A.R. policy's implementation emphasised the C.A.R. policy stated in Mayor Regulation No. 28 of 2020 concerning
Guidelines for Implementing Restrictions on Community Activities. The Restrictions on Community Activities (C.A.R.) have implemented to handle the spread of Corona Virus 2019 (Covid-19) Semarang City. However, before enacting this regulation, self-isolation is only needed based on the mayor of Semarang's appeal. This policy is to suppress the spread of Covid-19, which has not shown a graphical decline. Studies conducted by [12]-[15] show that self-isolation could stop the transmission of Covid-19. It is a system of epidemiological surveillance for the cases of Covid19 with no symptoms and potential Covid-19 disease carriers.

Although self-isolation has proven effective, the self-isolation policy's implementation should consider informal sector workers' conditions due to their low salary and low income. Of course, they will suffer from many difficulties. In this study, informal sector workers participate in the informal economy, who do not have access to secure work, benefits, welfare protection, representation, low-income workers, working as day labourers, and no savings. These include tour leaders, online drivers, and shopkeepers who cannot work from home because they must work at the workplace. As Nicola et al. [16] also noted, self-distancing and self-isolation have reduced the workforce across all economic sectors, including primary, secondary, and tertiary sectors, and caused many lost jobs. The World Health Organization [17] said that the pandemic is now affecting 210 countries and territories. Vaccine discovery, appropriate treatment, and physical distance are ways to break the chain of transmission. Full or partial locking measures are applied throughout the world, affecting more than 5 billion people. For most of the two billion workers and business owners in the informal economy, stopping work or working remotely from home is not an option. Staying home means losing their jobs and livelihoods, i.e., "dying from hunger or the virus." It is the real dilemma facing the informal economy workers.

In 2019, the number of workers in Indonesia working in the informal sector had reached 57 per cent or around 74 million workers. Out of that figure, as many as $\mathbf{2 5}$ million people, or about nine per cent, live below the poverty line. The Purchasing Manager Index survey on the sub-component of labour in some sectors shows that the manufacturing industry is among the first to reduce work due to decreased production and factory closure due to low revenue figures [18]. Based on the online survey conducted part-time from March 29 to April 13 by Abdul Latif Jamel Poverty Action Lab [18] in early 2020, 55 per 
cent of male and female workers who had previously worked typically became no longer working because of Covid-19. Their income falls below the poverty line because the company where they use does not operate temporarily. If so, self-isolation affects marginalising vulnerable groups' position to the poor due to the income falls below the poverty line. The issues are how the vulnerable cope with the condition, including how they think and act and the government's solution to the situation's anticipation so that vulnerable groups do not worsen.

\section{Literature Review}

The term rational and non-rational model is a concept that refers to the organisation of the human mind, introduced by Lévi-Strauss [19] in his book Structural Anthropology. This concept was discovered by Lévi-Strauss, examining the native tribe of Yanomamo, who inhabits the South American rainforest region. They live in the Amazon rainforest between the border of Brazil and Venezuela. Because their residence area is very remote and unreachable, they were only recognised by outsiders at the beginning of the 20th century. The life of the Yanomamo has now become one of the most studied ethnic groups by modern science. At Yanomamo, Levi-Straus found a unique organisation of thought when they deal with illness. They heal diseases by magical means by making offerings to the spirit. They assume that the pain for them is due to evil spirit disorder. It is called the healing method with a magic-religious model or non-rational model. They only knew how to cure medically (rational model) after the missionaries entered modernisation around the beginning of the 20th century.

Since Levi Straus argued that practically in all human beings, there is an essential genetic inheritance, i.e., structuring, the ability to structure, arrange a structure, or embed a particular form to the phenomena it faces. In everyday life, what is heard and witnessed by humans is an embodiment of this internal structure's existence. However, this embodiment is never complete. A structure only manifests in a context, just as a sentence in language forms a language structure. The relations of language in the deep structure have simplified binary oppositions (binary oppositions as organisations of thought and human culture contribute to responding to reality).

Many researchers developed the Lévi-Strauss model to study cultures, such as [20]. Their study focusses on how structuralism is employed in exploring culture within a peasant society in natural, though. Structuralism studies applied to examine complex societies facing tragedies; in this case, the
COVID-19 pandemic has not yet become much of a focus. Theoretically, when facing them, humans still must live it with reasoning and adaptive structure of action to even make it alive. Therefore, this study seeks to use structuralism to find deep structures in mindset models reflected in vulnerable groups' surface structures amid a pandemic. Based on the review of Lévi-Strauss [19] explanation on the structure of actions that are aware of citizens in responding to self-isolation policies, their mindset becomes citizens' cognitive structure (deep structures). Binary opposition's perspective generally determines the way of thinking of citizens: nonrational or rational.

For citizens controlled by rational thought, it is assumed that self-isolation is a sensible policy because transmission of the virus is solely be prevented by avoiding oneself. At least, epidemiology has taught much information through the media. So, self-isolation is the recommended solution on a scientific basis to cut the transmission of the virus. People experience self-isolation due to rational thinking models guiding them. Furthermore, the result of this method is compliance.

Meanwhile, residents who use non-rational thinking assume that avoiding COVID-19 does not have to isolate themselves. They consider that the COVID-19 pandemic is God's form of anger due to human behaviour that has been transcendent to the limit. So, they act to not self-isolation but worship God and apologise for mistakes and sins. This action is influenced by a way of thinking called the magicreligious model. The output of the model, people do not have to be obedient to undergo self-isolation. They are still doing routine activities to make money by asking for protection from God.

\section{Materials and Methods}

This study applies an ethnographic method to explore and understand (verstehen) the reality and dynamics of views, beliefs, and strategies of the informants to overcome crises. This study takes informal workers with low incomes, such as online drivers, shop assistants, and tour guides who cannot work from home because of their workplace nature. In this study, pseudo-names are used for the informants. Indepth interviews were conducted with 25 informants working in the informal sectors, five informants as tour guides, ten informants, the online drivers, conventional drivers, five informants, and five informants: for more detail about informants. Please refer to Table 1 for the informants' profile.

This research is conducted from March 15 to May 20, 2020, with in-depth interviews collected by phone through video call. The two-hour interviews 
consist of questions and answers for each informant. The results of the interview are recorded and then analysed. The taxonomic analysis applied to classify views and create patterns of economic vulnerability experienced by vulnerable groups. This study takes informal workers with low incomes, such as online drivers, shop assistants, and tour guides who cannot work from home due to their work nature. The study was conducted in Semarang City, in which 3.9 per cent of people live with income below the poverty line, i.e., IDR 474,930/monthly.

\section{Results}

\subsection{Achievements of Semarang City Development}

Based on data from the Bureau Statistics Indonesia (B.P.S.) of Central Java Province, the achievement of macro development indicators in Semarang City in 2019 shows encouraging numbers. The macro indicators are (1) economic growth reaching 6.86 per cent; (2) the poverty rate is 3.98 per cent, while the average poverty rate in Central Java is 11.41 per cent; (3) Open Unemployment Rate (T.P.T.) 4.54 per cent while Central Java 4.25\%; and the Human Development Index (HDI) is 82.72 while the average in Central Java is 71.73. HDI Semarang City is far above the average of 35 regencies/cities in Central Java. High and low HDI numbers are measured from the components of Life Expectancy (UHH), Length of School Expectation (H.L.S.), Average Length of School (R.L.S.), and Purchasing Power Parity (P.P.P.).

Starting from some macro indicator achievements, compared to 35 other districts/cities in Central Java, Semarang City has a prominent achievement figure. However, during the crisis, this achievement was disrupted, especially regarding city inhabitants working in the informal sector such as tour guides, online motorcycle taxis, conventional motorcycle taxis, and shop assistants. Based on B.P.S. figures, the Semarang City poverty line in 2019 is IDR. 474,930/month. The average income of those working in the informal sector before the epidemic ranged from IDR. 1,000,000 - IDR. $2,500,000$. This amount of income was enough to meet their basic needs. However, it was dropped extremely to IDR. 0 - IDR. 1 million or below the poverty line due to the execution of Semarang's city's self-isolation policies. Experience with no income occurred due to the work's character that depends on the existence of consumers. This situation calls upon the study to explore and analyse their adaptation patterns to vulnerability and their mindset and response to self-isolation policies executed.

\subsection{Demography Profile of Informants}

This study uses informants as many as 25 people who work daily in the informal sector. They have diverse backgrounds in terms of occupation, age, gender, marital status, and income. The variety of information about informants, as seen in Table 1.

Table 1. Profile of Informants

\begin{tabular}{|c|c|c|c|c|c|c|c|c|}
\hline \multirow[t]{2}{*}{ Profession } & \multicolumn{2}{|c|}{ Age } & \multicolumn{2}{|c|}{ Education } & \multicolumn{2}{|c|}{$\begin{array}{l}\text { Marital } \\
\text { Status }\end{array}$} & \multicolumn{2}{|c|}{ Income } \\
\hline & $\mathrm{a}$ & $\mathrm{b}$ & $\mathrm{a}$ & $\mathrm{b}$ & $\mathrm{a}$ & $\mathrm{b}$ & $\mathrm{a}$ & $\mathrm{b}$ \\
\hline Tour Guide & 3 & 2 & 4 & 1 & 5 & 0 & 3 & 2 \\
\hline $\begin{array}{l}\text { Online } \\
\text { Driver }\end{array}$ & 6 & 4 & 6 & 5 & 5 & 0 & 6 & 4 \\
\hline $\begin{array}{l}\text { Conventional } \\
\text { Driver }\end{array}$ & 4 & 1 & 4 & 1 & 5 & 0 & 4 & 1 \\
\hline $\begin{array}{l}\text { Shop } \\
\text { Assistant }\end{array}$ & 1 & 4 & 4 & 1 & 5 & 0 & 3 & 2 \\
\hline
\end{tabular}

Note: Age: a. 20 - 30, b. >30-40, Education a. < S.D., b. S.M.P. and above (S.M.A.), Marital Status; a. Married,

b. Unmarried, Income/month: a. IDR 0 - IDR 500,000,

b. > IDR500,000 - IDR 1,000,000

Table 1 shows informants' classification according to the type of work, age, level of education, marital status, and monthly income. From table 1, we found the four types of informants. First, tour leader of five informants, consisting of three informants aged 20-30 years old, two aged 40-50 years old, and one high school graduate, and four informants did not complete their junior high school. Five informants are currently married with monthly incomes ranging from > IDR 0 - IDR. 500,000. The second classification consists of ten informants consisting of online motorcycle taxi drivers. Six informants are aged 20-30 years old, four aged 31-40 years old and four graduated from junior high school, and six with elementary school education. Five informants are married, and six informants have an income with a range $>0$ to five hundred thousand rupiahs monthly, and four informants earn > IDR. 500,000 - IDR. $1,000,000 /$ month.

The third category is five informants of conventional motorcycle taxi drivers, including four aged 20-30 years old, one aged 31-40 years old, four graduating from senior high school, and six informants who do not graduate from junior high school. In terms of marital status and income, five informants are married, with four earning >IDR. 0 IDR. 500,000/month, and four informants earn IDR. 500,000 - IDR. 1,000,000/month. The fourth classification is shop attendants totalling five informants consisting of four informants aged 20-30 years old, one aged 31-40 years old; four graduated 
from Senior high School, and one did not get past junior high school. Five informants are married in terms of their marital status and income, with four informants earning IDR. 0 - IDR. 500,000, and one earns IDR. 500,000 - IDR. 1,000,000.

\subsection{Pattern of Informants Vulnerability}

However, due to the COVID-19, the Tour and Travel company, the informants' partner, no longer operates. Although in a condition of concern after the appeal for self-isolation, Uli complied with the government's advice, isolating herself, staying at home, and not going to work. Even if she needs to go out, Uli will follow the government's health protocol to keep a distance from others, wear a mask, wash hands, and take a bath when returning home. Complying with this protocol by Uli is immensely rational because he has a six-year-old child at home. He believes that coronavirus is very dangerous for kids and children, and it has serious consequences and causes death either. As a result of complying with this appeal, on the other hand, Uli lost his source of income. Uli has no income for three months. Previously he earned an average of IDR. 2,400,000 a month. The total income included in the category of the population with income far above the poverty line (IDR. 474,930) in Semarang.

Hedi, a 27-year-old man married with one child, has a similar experience. He works as a car online driver. He said, "I was forced to isolate myself, or at least take care of myself when carrying passengers because I was afraid of contracting the virus from the passengers." Initially, he was very strict in following self-isolation appeals, but he still must work because of his responsibility to meet his household needs. However, his income dropped sharply. Before the pandemic, he can earn more than IDR. 100,000 per day, with an average of 25 trips a day with the monthly income was IDR. 2,500,000. However, now his income is only IDR. 1,000,000 per month. It decreases by around 60 per cent or IDR. 1,500,000 from the previous income. Therefore, Hedi experienced a situation where his income per month decreased dramatically due to his self-isolation request.

Yudi is a 37-year-old man who has a family with one child. His wife is unemployed and a housewife. He worked as a shop assistant at a supply shop and souvenirs for Hajj and Umrah. Before Corona, his salary was IDR. 1,100,000 per month. However, due to umrah and hajj pilgrimage's travel restrictions, the shop could no longer afford to employ Yudi due to no customers. The shop owner promised him that there would be a delay in payment of salaries while waiting for the conditions to return to normal. Yudi is an informant who has experienced income delays due to the crisis. Thus, the story experienced by each informant and their economic conditions is presented in Table 2 below. This table contains 25 informants as interviewed based on these professional classifications: five tour guides, ten online drivers, five conventional motorcycle taxi drivers, and five shop assistants.

Table 2. The informant's income before and during the COVID-19 pandemic and income status.

\begin{tabular}{|c|c|c|c|c|}
\hline Profession & Freq. & $\begin{array}{l}\text { Income } \\
\text { before } \\
\text { crisis } \\
\text { (IDR) }\end{array}$ & $\begin{array}{l}\text { Income } \\
\text { during a } \\
\text { crisis } \\
\text { (IDR) }\end{array}$ & $\begin{array}{l}\text { Income } \\
\text { Status }\end{array}$ \\
\hline Tour Guide & 5 & 2.400 .000 & - & $\begin{array}{l}\text { Not } \\
\text { revenue }\end{array}$ \\
\hline $\begin{array}{l}\text { Online } \\
\text { Driver }\end{array}$ & 10 & 2.500 .000 & 1.000 .000 & $\begin{array}{c}\text { Decreased } \\
\text { revenue }\end{array}$ \\
\hline $\begin{array}{l}\text { Conventional } \\
\text { Driver }\end{array}$ & 5 & 1.500 .000 & 750.000 & $\begin{array}{l}\text { Decreased } \\
\text { revenue }\end{array}$ \\
\hline $\begin{array}{l}\text { Shop } \\
\text { Assistant }\end{array}$ & 5 & 1.100 .000 & - & $\begin{array}{c}\text { Wage } \\
\text { payments } \\
\text { postponed }\end{array}$ \\
\hline
\end{tabular}

Based on table 2, the pandemic has a paradoxical effect on the household economy of vulnerable groups working in the informal sector. The pattern of vulnerability consists of three levels. First, those who experience lost income because their workplaces are no longer in operation. Second, those who experience a decline in revenue due to decreased purchasing power impact declining income. Third, those who experience delays in payment of income because their workplace experiences a decrease in income.

\subsection{Cultural Responses of Vulnerable Groups}

The conditions of vulnerability experienced by informal workers are diverse in terms of income. Diversity is related to the perspective that underlies the way they think and responds to policies of selfisolation. This fact proved from the interviews with 25 informants by telephone (video call). Based on the taxonomic analysis found that informants' perspectives manifested into two categories. First, those who believe a manifestation of God's anger due to human behaviour goes beyond natural resources exploitation. To avoid contamination, they must go to pray and apologise for all the mistakes. If they apologise, then they will get protection from G.O.D. from the dangers of COVID. Those who think such methods are called adherents to the religious-magic model or the non-rational model. Most informants who have non-rational thinking patterns refuse to undergo isolation due to the requirement to meet the families' needs. 
For this first type of response, the picture is as described by Narso (39 years old), an elementary school graduate, married, and has three children. Narso worked as a conventional motorcycle taxi driver, which each operates at the Kagok motorcycle taxi station in Semarang. He believed the plague was God's test for humans. Against this test, he felt terrified, and to keep him away, he did 'repentance,' pray and carry out his obligations to God on time. For him, a virus is like a call to pray, which allows him to understand the meaning of 'going home' to God. Second, those who argue that the virus is a natural phenomenon, a type of disease originating from Wuhan. This virus spreads to other countries through the process of transmission from one person to another. Thus, the only way to avoid viruses is to selfisolation. They obey the obligation of self-isolation despite losing their income. They believe that this perspective will save them. Those who follow this perspective are called rational models. A complete picture of informants who respond to self-isolation is seen in Table 3a and Table 3b below:

Table 3a. The Cultural responses of informal workers

\begin{tabular}{cccc}
\hline Type of Profession & $\begin{array}{c}\text { Vulnerable } \\
\text { Category }\end{array}$ & Education & Freq. \\
\hline Tour Guide & Lost Income & $<$ JHS & 4 \\
& & JHS & 1 \\
Online Driver & Lost Income & $>$ JHS & 6 \\
Conventional & Decline in & $<$ JHS & 4 \\
Driver & Income & $>$ JHS & 1 \\
Shop Assistant & Delay & $<$ JHS & 4 \\
& Income & $>$ JHS & 1 \\
\hline
\end{tabular}

Note: J.H.S. is Junior High School

Table $3 b$. The cultural responses of informal workers to perspective and self-isolation

\begin{tabular}{|c|c|c|c|}
\hline Profession & $\begin{array}{l}\text { Vulnerable } \\
\text { Category }\end{array}$ & Perspective & Self-Isolation \\
\hline \multirow[t]{2}{*}{ Tour Guide } & \multirow{2}{*}{$\begin{array}{l}\text { Lost } \\
\text { Income }\end{array}$} & $\begin{array}{l}\text { Non- } \\
\text { Rational }\end{array}$ & Ignore \\
\hline & & Rational & Obey \\
\hline \multirow{2}{*}{ Online Driver } & \multirow{2}{*}{$\begin{array}{l}\text { Lost } \\
\text { Income }\end{array}$} & $\begin{array}{l}\text { Non- } \\
\text { rational }\end{array}$ & Ignore \\
\hline & & Rational & Obey \\
\hline \multirow{2}{*}{$\begin{array}{l}\text { Conventional } \\
\text { Driver }\end{array}$} & \multirow{2}{*}{$\begin{array}{l}\text { Decline in } \\
\text { Income }\end{array}$} & $\begin{array}{l}\text { Non- } \\
\text { rational }\end{array}$ & Ignore \\
\hline & & Rational & Obey \\
\hline \multirow{2}{*}{$\begin{array}{l}\text { Shop } \\
\text { Assistant }\end{array}$} & \multirow{2}{*}{$\begin{array}{l}\text { Delay } \\
\text { Income }\end{array}$} & $\begin{array}{l}\text { Non- } \\
\text { rational }\end{array}$ & Ignore \\
\hline & & Rational & Obey \\
\hline
\end{tabular}

Table 3 shows the variation of views, namely rational and non-rational, in each type of informant profession. Nevertheless, the number of informants who have non-rational ideas is more dominant than those with rational views. Generally, an informant with a non-rational perspective comes from a low educational background, and they tend to ignore selfisolation. Meanwhile, those who have a rational view are generally more highly educated, and this informant manages to comply with self-isolation provisions. Thus, the appeal for self-isolation has given rise to binary opposition from informant actions and ways of thinking. Self-Isolation has also brought down most of the business sector, especially the informal sector.

\section{Discussion}

Self-isolation is the sine qua non, whether it is carried out on the government policy or carried out independently by a person. Self-isolation is a control system that emerged to prevent people's movement during a particular period in hindering disease transmission [21]-[23]. It is identical to the self-exile of a person or group of people due to the pandemic. In epidemiological discourse, the term self-isolation is often equated with medical quarantine or isolation towards healthy individuals and individuals that have been infected so that they do not transmit the disease to each other. Although the concept of quarantine created to prevent the spread of animal diseases, quarantine is also used to avoid the spread of disease among humans [24]. However, based on field observation, self-isolation is an effort to avoid transmission that affects the vulnerable group's income. In this case, the vulnerable groups earn an average above the poverty line, rely on daily facts, do not have savings, and "rob Peter to pay Paul." Debt is an inherent part of vulnerable groups' lives, and they mostly work in the informal sector [18].

Notable impact experienced by the vulnerable groups categorises the groups into three vulnerable sub-groups. First, those who experience job and income lost. It experienced by informants who work as tour guides. They work very much dependent on the tourists. Therefore, pandemic causes the tourism sector to no longer able to operate. Second, the group experienced a decrease in income due to the decline in their purchasing power because of declining income. This category involves informants who work both online and conventional motorcycle taxis. They work highly dependent on consumers who use motorcycle taxi services. However, the causes most residents choose to stay at home. That is why they experience a decrease in income between 50-60 per cent. Third, those who experience delayed payment 
of wages due to workplaces receive decreased income. This category is experienced by informants who work as shop assistants whose business types are also affected by Covid-19, such as stores that provide hajj equipment. During the pandemic, the activities of Hajj and Umrah has stopped temporarily. It causes the store income to drop dramatically. Therefore, the shopkeeper chooses to lay off employees and delay the salary payment until the conditions better.

To respond to the policy of self-isolation, each vulnerable group has a specific variation in its response. Some reject self-isolation, which means ignoring the obligation to stay at home. Meanwhile, many received self-quarantine accompanied by disciplinary action following the obligation to stay at home until stipulatory time. The diversity of responses is a consequence of circumstances that indicate an order in the human mind's organisation. For Lévi-Strauss [19], it is not impossible due to a primary human ability inherited genetically. This ability exists in all humans, namely the ability to structure or construct a structure on the phenomena encountered.

Furthermore, the structure in the form of an action pattern is a surface structure that reflects the human's deep structure or a human mind. The internal structure contains relations of ideas, concepts, and thoughts or a cultural phenomenon that is related to several other phenomena that, at a certain point, determine the meaning of the phenomenon. The relationships that exist in the internal structure can be simplified into a binary opposition model. It is relevant to Lévi-Strauss thought (1976) that cultural studies need to be directed at how the human mind mechanism works and reflects in the structure. The human mind mechanism works and reflects in the surface structure. According to Lévi-Strauss [19], the study of natural thought processes has been heavily influenced by unnatural conditions. The study of fairy tales (myths) by Sturrock [25] is often put forward because it embodies a simple community mind where little things are found.

The similarity is the foundation of Lévi-Strauss to study human reasoning. Another reason for studying myths is that they are similar to languages where myths and languages are both communication media to convey messages, langue and parole aspects of myths demonstrated by the presence of myths in reversible and non-reversible time. It also proposed a view because the meaning in language lies in the combination of phonemes. Myth examined by looking at the combination of various characters and their actions and their respective positions in the combination. This equation of myth and language led Lévi-Strauss to issue a theory that said," myth is language, functioning on an especially high level where meaning succeeds practically at 'taking off' from the linguistic ground on which it keeps on rolling."

For Lévi-Strauss [19], the study of culture is not merely revealing the surface structure as a systemic reflection of the workings of the human mind organisation, but at the same time as a framework for cultural studies is carried out through the disclosure of two types of structures namely deep structures and surface structures simultaneously. In this study, the inner structure is known through tracing discourse, which shows the binary opposition's mindset. The concept contains ideas and ideas in the formula of magic-religion models (non-rational models) and rational models.

Based on field observations, two types of reasons have found with binary opposition in different vulnerable groups. On the fieldwork basis, it is found that the way they responded to selfisolation, resistance to self-isolation, ignoring the obligation to carry out health protocols, and ignored to stay at home. For them, fulfilling basic needs is jihad fisabilillah, while life and death are a matter of God. Reasoning thought has become a deep structure for vulnerable loss income groups. However, not all of these vulnerable groups are irrational. Some have rational reasons to believe that safety and health are more important than income. Health for them is an investment in life, while income is only something for a living. This mindset is found in vulnerable income groups with a background in Junior High School education. Those who have consciousness undergo adaptive isolation themselves with a new way of life. This perspective becomes a deep structure among those on loss incomes manifested in accepting self-isolation policies.

Vulnerable groups in decline income experience have the same expression for informants working as an online motorcycle taxi and conventional motorcycle taxi. This group is also divided into two sub-logics, namely the magic-religion model and the rational model. For those with a non-rational model of reasoning, their educational background is in elementary school. They ignore the obligation to isolate themselves, as well as health protocols. Looking for a living is the main thing based on the intention to do jihad fisabilillah. It believed that they would avoid the threat of COVID-19 and other threats. The vulnerable group has lost the income among those who have rational thought. Like those who reason, they are educated to graduate from junior high school, carry out self-isolation, and follow the health protocol. These reasoning thought has become a deep structure among the decline- 
income group. The same pattern also manifests in vulnerable groups in the category of delay-income for informants who work as shop assistants.

The response pattern is the same as the other two groups above, those who have the magic-religion mind and rational model. For non-rational reasoning models generally also have an elementary education background. The tendency is also to neglect selfisolation and disregard the health protocols. The Daqlam things of earning a living also share the view of the two groups mentioned above-some in the group have the same mindset, where this logical reasoning is the deep structure. Self-isolation has thus significant to a new cultural structure among the vulnerable workers in the informal sector. It is a consequence of the implementation of self-isolation policies that tore up most of the informal sector. Much research states that citizens' isolation from outbreaks that a country has ever experienced generally leads to a contraction in the informal sector [26]-[28].

Many solutions proposed to overcome this problem. For example, Israr et al. [28] suggest handling the vulnerable groups when facing outbreaks in two ways: meeting basic needs and providing facilitation to them to have sustainable livelihoods to independently re-income. Relevant to the implementation of self-isolation for a vulnerable group, the government is expected to provide a policy breakthrough to provide facilitation support suggested by Israr et al. [31]. It is done by providing social security assistance programs by providing direct cash to overcome difficulties in meeting basic needs from the government [29], [30]. It focused on distributing the budget and implementation of poverty alleviation programs and encouraging the realisation of health insurance covering all residents, particularly low-income families. The insurance system can guarantee all society levels regardless of economic vulnerability and give them good quality health services and social protection. To date, the health insurance borne by the Social Security Organizing Agency (BPJS) has not completed everything because it only serves the public who paid monthly contributions. For community groups who work in the informal sector with low income and are not included in receiving contributions. Delay in paying dues can have an impact on termination and providing health services to them.

The government also needs to allocate public funds to strengthen primary health services for the poor. These services include access to health education, clean water, nutrition, immunisation, and various infectious and non-communicable diseases. It is a social security protection program provided to vulnerable groups to have income or sustainable livelihoods. Other examples of programs are the expansion of social assistance, pre-employment cards, the formation of BUMDES (Village-Owned Enterprises). Besides assisting in the cost of electricity and free water, and tax breaks for workers and MSMEs. An economic recovery program for the business world is also related to the informal sector [28]. Without adequate support from the government with two approaches, the vulnerable, vulnerable groups and low-income informal workers will experience increasingly severe vulnerabilities. They can lead to the birth of an unfavourable situation. While on the other hand, they also belong to vulnerable groups at risk of contracting and potentially spread the infection.

\section{Conclusion}

The current COVID-19 pandemic, which continues to spread, has a paradoxical effect on informal sector workers. Those who are members of vulnerable groups experience a decline, delay, and loss of their income due to self-isolation appeals. Thus, appeal Self-isolation has also divided the informant's mindset into rational and non-rational models. The mindset model is related to the informant's educational background. The rational mindset applies to informants who stick to appeals for self-isolation. Non-rational ones are related to informants who are forced to violate appeals due to family responsibilities, even though their income is still insufficient or below the Semarang poverty line. Policies to reduce the pandemic's impacts need to be discussed by choosing the right strategy to address this issue more precisely and on target.

In this context, the researchers mention two strategies that need to be carried out together. First, strategies to access basic needs with a focus on direct assistance to targeted vulnerable groups. Second, assist that can facilitate vulnerable groups to support their sustainable livelihoods. Anthropologically, this research needs to be followed by discussing how the government formulates policies for vulnerable groups. It aims to develop anthropology policy reforms. From this review, we will discuss how to formulate "public policies" that have been agreed upon in advance to protect the layers of society that improve them, allowing them to stay healthy and productive. 
References:

[1] R. Baldwin, B. Weder, and D. Mauro, "Economics in the time of COVID-19: A new eBook." Accessed: February 01, 2021. [Online]. Available: https://www.ecdc.europa.eu/en/geographicaldistribution-2019-ncov-cases.

[2] W. H. Organization, "Situation Report-82 HIGHLIGHTS," 2020, doi: 10.1101/2020.03.23.20041913.

[3] C. H. Yan, F. Faraji, D. P. Prajapati, C. E. Boone, and A. S. DeConde, "Association of chemosensory dysfunction and COVID-19 in patients presenting with influenza-like symptoms," Int. Forum Allergy Rhinol., vol. 10, no. 7, pp. 806-813, Jul. 2020, doi: 10.1002/alr.22579.

[4] S. J. Zhou et al., "Prevalence and sociodemographic correlates of psychological health problems in Chinese adolescents during the outbreak of COVID-19," Eur. Child Adolesc. Psychiatry, vol. 29, no. 6, pp. 749-758, Jun. 2020, doi: 10.1007/s00787020-01541-4.

[5] Q. Wang, M. S.-S. of the total environment, and undefined 2020, "A preliminary assessment of the impact of COVID-19 on environment-A case study of China," Elsevier, Accessed: February 01, 2021. [Online]. Available: https://www.sciencedirect.com/science/articl e/pii/S0048969720324323?casa_token=KQF lrcdgrzkAAAAA:7KaPOod5ofD2fsFSVu8B ifm1DfVIEQp3bLMO88gR-Zfkzp75dLHO003JwiPuTJu7KrZkiTKx8iD.

[6] R. Djalante, J. Lassa, D. Setiamarga, ... A. S.P. in D., and undefined 2020, "Review and analysis of current responses to COVID-19 in Indonesia: Period of January to March 2020," Elsevier, Accessed: February 01, 2021. [Online]. Available: https://www.sciencedirect.com/science/articl e/pii/S2590061720300284.

[7] D. Ting, L. Carin, V. Dzau, T. W.-N. medicine, and undefined 2020, "Digital technology and COVID-19," nature.com, Accessed: February 01, 2021. [Online]. Available:

https://www.nature.com/articles/s41591-0200824-5.

[8] S. Whitelaw, M. Mamas, E. T.-T. L. D. Health, and undefined 2020, "Applications of digital technology in COVID-19 pandemic planning and response," Elsevier, Accessed: February 01, 2021. [Online]. Available: https://www.sciencedirect.com/science/articl e/pii/S2589750020301424.

[9] X. P.-I. J. of M. S. (1971-) and undefined 2020, "Application of personal-oriented digital technology in preventing transmission of COVID-19, China," Springer, Accessed: February 01, 2021. [Online]. Available: https://link.springer.com/article/10.1007/s11 845-020-02215-5.

[10] K. Allard, T., \& Lamb, "Exclusive: More than 2,200 Indonesians Have Died... - Google Scholar," 2020. https://scholar.google.com/scholar?hl=en\&as _sdt $=0 \% 2 \mathrm{C} 5 \& \mathrm{q}=$ Exclusive $\% 3 \mathrm{~A}+$ More + than $+2 \% 2 \mathrm{C} 200+$ Indonesians+Have+Died+with+ Coronavirus+Symptoms $\% 2 \mathrm{C}+$ data+shows $\%$ 2C++https\%3A\%2F\%2Fwww.reuters.com.\& btnG $=($ accessed February 01, 2021).

[11] J. P. Bean, "Indonesia's 'new normal' a disaster in the making.," Asia Times, 2020. https://scholar.google.com/scholar?hl=en\&as _sdt $=0 \% 2 \mathrm{C} 5 \& \mathrm{q}=$ Indonesia $\% 27 \mathrm{~s}+\% 27 \mathrm{new}+$ normal\%27+a+disaster+in+the+making.+Asi $\mathrm{a}+$ Times\&btnG $=$ (accessed February 01, 2021).

[12] A. Spinelli and G. Pellino, "COVID-19 pandemic: perspectives on an unfolding crisis," Br. J. Surg., vol. 107, no. 7, pp. 785787, May 2020, doi: 10.1002/bjs.11627.

[13] F. Pinotti et al., "Lessons learnt from 288 COVID-19 international cases: importations over time, effect of interventions, underdetection of imported cases," medrxiv.org, doi: 10.1101/2020.02.24.20027326.

[14] T. Laidlaw, "Pandemic Stories: Rhetorical Motifs in Journalists' Coverage of Biomedical Risk," Minerva, vol. 57, no. 4, pp. 433-451, Dec. 2019, doi: 10.1007/s11024-019-093834.

[15] K. A. Mason, "H1N1 Is Not a Chinese Virus: the Racialisation of People and Viruses in Post-SARS China," Stud. Comp. Int. Dev., vol. 50, no. 4, pp. 500-518, Dec. 2015, doi: 10.1007/s12116-015-9198-y.

[16] M. Nicola et al., "The socioeconomic implications of the coronavirus pandemic (COVID-19): A review," Int. J. Surg., vol. 78, pp. 185-193, Jun. 2020, doi: 10.1016/j.ijsu.2020.04.018.

[17] W. H. Organization, "COVID- 19 health equity impact policy brief: informal workers," 2020. Accessed: February 01, 2021. [Online]. Available: http://www.who.int/about/licensing. 
[18] M. R. Ramadhana, "A dataset for emotional reactions and family resilience during COVID-19 isolation period among Indonesian families," Data Br., vol. 31, p. 105946, Aug. 2020, doi: 10.1016/j.dib.2020.105946.

[19] C. Lévi-Strauss, "Structural Anthropology.," New York: Basic Books, 1976. https://scholar.google.com/scholar?hl=en\&as _sdt $=0 \% 2 \mathrm{C} 5 \& \mathrm{q}=$ Levi-

Strauss\%2C+C.+\%281976\%29.+Structural+ Anthropology.+Vol.+2.+New+York\%3A+B asic+Books.\&btnG $=($ accessed February 01 , 2021).

[20] A. González-Ruibal, "House societies vs. kinship-based societies: An archaeological case from Iron Age Europe," J. Anthropol. Archaeol., vol. 25, no. 1, pp. 144-173, Mar. 2006, doi: 10.1016/j.jaa.2005.09.002.

[21] M. K. Anser et al., "Does communicable diseases (including COVID-19) may increase global poverty risk? A cloud on the horizon," Environ. Res., vol. 187, p. 109668, Aug. 2020, doi: 10.1016/j.envres.2020.109668.

[22] M. Bodrud-Doza, M. Shammi, L. Bahlman, A. R. M. T. Islam, and M. M. Rahman, "Psychosocial and Socioeconomic Crisis in Bangladesh Due to COVID-19 Pandemic: A Perception-Based Assessment," Front. Public Heal., vol. 8, Jun. 2020, doi: 10.3389/fpubh.2020.00341.

[23] M. Shammi, M. Bodrud-Doza, A. R. M. Towfiqul Islam, and M. M. Rahman, "COVID-19 pandemic, socioeconomic crisis and human stress in resource-limited settings: A case from Bangladesh," Heliyon, vol. 6, no. 5, May 2020, doi: 10.1016/j.heliyon.2020.e04063.

[24] H.-L. Quach and N.-A. Hoang, "COVID-19 in Vietnam: A lesson of pre-preparation," $J$. Clin. Virol., vol. 127, p. 104379, Jun. 2020, doi: $10.1016 /$ j.jcv.2020.104379.

[25] J. Sturrock, "Structuralism And Since: From Levi Strauss To Derrida," 1979. Accessed: February 01, 2021. [Online]. Available: https://pdfs.semanticscholar.org/f616/23a80c ed41b5ad358e6855d00e1a487d2f47.pdf.

[26] R. N. Lui et al., "Overview of guidance for endoscopy during the coronavirus disease 2019 pandemic," Journal of Gastroenterology and Hepatology (Australia), vol. 35, no. 5. Blackwell Publishing, pp. 749-759, May 01, 2020, doi: 10.1111/jgh.15053.

[27] F. Dwi Sakti Kartika and M. Helmi, "Meta- analysis of community's adaptation pattern with tidal flood in Pekalongan City, Central Java, Indonesia," e3s-conferences.org, doi: 10.1051/e3sconf/201.

[28] M. Israr, H. Khan, D. Jan, N. Ahmad, and A. Professor, "Livelihood Diversification: A Streatagy for Rural Income Enhancement," $J$. Financ. Econ., vol. 2, no. 5, pp. 194-198, Sep. 2014, doi: 10.12691/jfe-2-5-10.

[29] M. H. Hidayattuloh, A. Nur Bambang, and A. Amirudin, "Environmental-based budget planning in The Tegal Regency Government," e3s-conferences.org, doi: 10.1051/e3sconf/201.

[30] A. Amirudin, "Issues in Journalism Coverage at the Suara Merdeka Newspaper," e3sconferences.org, vol. 125, p. 02019, 2019, doi: 10.1051/e3sconf/201.

\section{Contribution of individual authors to the creation of a scientific article (ghostwriting policy)}

Amirudin Amirudin writing - original draft and investigation.

Jumadil Saputra writing - methodology, review, editing, investigation, and data analysis.

Teuku Afrizal writing - original draft, investigation, editing and data analysis.

M. Latip writing - methodology, review, and editing. A. Tarmizi writing - methodology, review, and editing.

\section{Sources of funding for research presented in a scientific article or scientific article itself \\ Report potential sources of funding if there is any}

\section{Creative Commons Attribution}

\section{License 4.0 (Attribution 4.0 \\ International, CC BY 4.0)}

This article is published under the terms of the Creative Commons Attribution License 4.0 https://creativecommons.org/licenses/by/4.0/deed.en _US 